\title{
Exploring The Social Marketing Impacts of Virtual Brand Community Engagement
}

\author{
I Ping Chiang \\ National Taipei University \\ E-Mail: ntpu.im.iplab@gmail.com \\ Shou En Tu \\ National Taipei University \\ E-Mail: grace05026@gmail.com \\ Ling Hui Wang \\ National Taipei University \\ E-Mail: betty1010177@gmail.com
}

\begin{abstract}
The number of people using online communities is rising. The study found that more consumers find and evaluate goods through social media networks. At the same time, marketers continue to promote brand recognition, but more importantly, to increase user engagement. However, the link between the brand community and social media has become the focus of the marketing staff and the public. But the academic research of the brand community and the social media in the past focused on brand loyalty. Thus, the aim of this study was to explore how virtual brand communities could create social impacts on their customers. This study will use a web survey from customers from Insightxplorer's Cyber Panel who intend to adopt a social network service. Factor analysis will be conducted to confirm the induced factors from literature review. Furthermore, PLS will be used to determine the variation in social networking sites' quality, brand communities' engagement, virtual community and equity. Finally, in-depth discussions and conclusions will be provided to inform research and practice.
\end{abstract}

Keywords: Social Media Marketing, Virtual Brand Community, Brand Community Engagement 


\section{INTRODUCTION}

With the rise of the Internet, social media has changed the way people communicate. According to eMarketer, in 2015, 196 million users worldwide were recorded on social networking sites (SNS), constituting $27.1 \%$ of the global population, and this number is projected to reach 2 billion by 2016. Consumers are more likely to discover and evaluate goods through social media networks, as marketers continue to promote brand recognition and more importantly, to increase user engagement. According to a survey by eMarketer on the use of social media as a marketing application by US businesses in 2015 , approximately $88.2 \%$ of enterprises have used social media as a marketing tool since 2015 , and this figure is expected to grow to $89.4 \%$ by 2017 . Accordingly, social media marketing continues to grow as more companies find it indispensable.

Facebook, with more than one billion users, is the most popular social networking platform among electronic retailers. Facebook is favored by e-tailers on other social media platforms such as Google+, Instagram, and Pinterest, because it enables direct interaction with potential customers and offers an unprecedented platform for customers to share product reviews (Nadeem, Andreini, Salo, \& Laukkanen, 2015). According to Social Media Examiner's 2015 Social Media Marketing Business Report, among Facebook, Twitter, LinkedIn, Google+, YouTube, and Pinterest, which are the most commonly used by marketers, Facebook remains the major social media platform for marketing. As can be seen from the report, most companies or advertisers choose Facebook as their primary social media platform for promoting product or brand information.

Although the link between a brand community and social media has become the focus of both marketing professionals and the public, the academic literature on the brand community and social media emphasizes brand loyalty. Studies of the diffusion of innovation and the brand community are scant. The present study therefore has the following objectives:

1. Through the literature, the paper explored the effects of SNS on social marketing, to establish a measurement framework to measure the relevance of these constructs.

2. To conduct an online survey and partial least squares (PLS) analysis to examine the relationships among virtual brand engagement, service characteristics of SNS and impact on social marketing. 


\section{THEORETICAL BACKGROUND}

\section{Brand Communities’ Engagement}

Consumer engagement is the main objective of co-creation and interaction to create consumer experiences that elicit specific mental states. Because a product cannot be experienced online, the role of network media such as e-retailer websites, intermediaries, and social networking sites becomes crucial (Brodie, Hollebeek, Juric, \& Ilic, 2011; Nadeem et al., 2015). Evans (2010) suggested a four-story engagement ladder of engagement, curation, creativity, and collaboration, enabling users to advance from simple earned and paid media to word-of-mouth media. Forrester (2007) applied a social science and technology consumption questionnaire to design a set of categories for participant segmentation: creator, communicator, commentator, collector, joiner, bystander, and inactive users. This study summarized the literature and activity indicators to identify five brand community engagements and activities: join, browsing/consume, comment, sharing, and creation.

\section{- Join}

A user who joins a social media network opens an account and creates a profile to connect with other users. Users can also join groups of people who share their interests (Frost \& Strauss, 2013). Members of LinkedIn, for example, can join groups focusing on business activities (Zaglia, 2013).

\section{- Browsing/Consume}

Users who engage in browsing or adopting on social media platforms absorb content from blogs, videos, podcasts, or status updates, and they collect information to make decisions, learn from others, or find entertainment (Li, 2011). According to Evans and Dave (2010), building strong customer engagement relies on reception. In social media, reception consists of downloading, reading, browsing, or listening to digital content. Reception is the starting point for almost all online activities, especially community activities.

\section{- Comment}

Fournier and Avery (2011) indicated that online consumers have become enthusiastic brand commentators in providing authoritative judgment and criticism to enterprises and brands. Social media platforms have empowered consumers to connect, 
share, collaborate, and create, and this has radically influenced and changed marketing methods (Hanna, Rohm, Crittenden, \& Singh, 2005; Walmsley, 2010). On Facebook, consumers can click the "Like" button to indicate support. On social media platforms, people comment on other people's blogs, news, status updates, or product evaluations. Individuals participate, support, and contribute to the ideas and opinions of others $(\mathrm{Li}$, 2011).

\section{- Sharing}

The activity of sharing involves people with the same interests in a community converging to exchange contact, build relationships, and share or discuss ideas (Zaglia, 2013). In a brand community, members who share interests can not only develop affinity, but also establish contact, thereby empowering the consumers. Sharing personal information, knowledge, and experience is an activity or cognitive dimension that reflects consumer engagement through active contributions made through shared knowledge within a social network (Brodie, Ilic, Juric, \& Hollebeek, 2013).

\section{- Creation}

Creation entails a user writing or uploading original multimedia content to a website, such as uploading a video to YouTube, a photo to Facebook, or music and podcasts to iTunes. Consumers write reviews of their products, open blogs, leave comments on other people's blogs, and write Wikipedia articles, thereby contributing more to social media content than others do (Frost \& Strauss, 2013). Franzia, Piliang, and Saidi (2015) argued that images and note posting are examples of public engagement in new media and cyberspace. The members of this virtual community engaged in the discussion based on interest and concern in their culture. representing a focus on cultural identity.Members of the virtual community base their interests and attention on culture to engagement in a discussion. The social network sites have the power to spread messages into the network of friends.

Wachter et al. (2013) argued that stronger engagement motivation would give the user a higher perceived value; Frost and Strauss (2013) pointed out that the minimum participation of Internet access, is receiving content on the web, browse their blogs, watching videos and photos, listen to podcasts and reading, higher participation of other Internet users, it is published on the web and forum comments and opinion. Therefore, this research integrated other studies to classify the type of engagement into low engagement of joining: join, browsing, receiving, commenting, sharing, and creating. 


\section{Service Characteristics of SNS}

Many scholars have investigated the characteristics of web service. Nadeem et al. (2015) stated that web service was helpful and responsive. Consumers' inquiries were responded to promptly (Wolfinbarger and Gilly, 2003). Ellahi and Bokhari (2013) believed that the characteristics and the reliability of a web service were the keys to increase the number of users, which could then bring profits to the company. With the rise of social networking websites, Ellahi and Bokhari (2013) identified six significant factors, which were efficiency, entertainment, community drivenness, privacy, user friendliness, and navigability. Hsiao (2010) found that the website's reputation, quality, and institutional assurance have considerable influence on trust in social commerce. In addition, Yang et al. (2015) implications for designing a social shopping website that increases consumer participation and positive behavioral outcomes are discussed. The results support the conclusion that social shopping website attributes as drivers of reciprocity, and positive electronic Word of Mouth (eWOM) and co-shopping were positioned as behavioral outcomes of reciprocity. Yoo et al. (2015) believed that e-commerce sites should be encouraged to provide a better EWOM environment for reciprocity and advanced EWOM system functionality, which enabled multiple channel communications as well as quick responses to customer requests. In summary, the study organized seven evaluative aspects of social networking website for the user: information, reciprocity, entertainment, reputation, interaction, similarity, and connectedness.

\section{- Information}

Ho et al. (2012) also believed that information quality consists of appropriateness, update quality, usefulness, accuracy, completeness, and relevance of the website. Yoo et al. (2015) pointed out that information also included content quality, the format quality, and the real-time presentation. Content quality referred to the accuracy, relevance, and completeness of information, while the format quality was concerned with the interface, the packaging, and the accessibility. The real-time presentation included the transmission quality, the information circulation, and the maintenance of previous information. The following hypotheses were suggested:

H1 : Information would encourage members of social networking websites to engage in a brand community.

H1a : Information would cause a low-level engagement in a brand community by members of social networking websites.

$\mathrm{H} 1 \mathrm{~b}$ : Information would cause high-level engagement in brand community by members of social networking websites. 


\section{- Reciprocity}

Chan and Li (2010) believed that reciprocity reflected a sense of duty and obligation to both individual members and the community, as a moral responsibility in consumer virtual community. Consumers seek others' advice to solve consumption problems. Meanwhile, members reciprocate the support they receive by sharing resources. Reciprocity therefore offers a mutually gratifying pattern of exchange of various resources. Reciprocity implied a belief in the ongoing relationship among members of a group (Landry et al. 2005; Uzzi, 1996; Warren, 1978). The following hypotheses were suggested:

$\mathrm{H} 2$ : Reciprocity would encourage members of social networking websites to engage in a brand community.

H2a : Reciprocity would cause a low-level engagement in a brand community by members of social networking websites.

$\mathrm{H} 2 \mathrm{~b}$ : Reciprocity would cause high-level engagement in brand community by members of social networking websites.

\section{- Entertainment}

Entertainment is the feeling of being sociable, cheerful, and happy, and referred to the way social media serves as a means for entertaining and escaping pressure (Lee, 2012; Kim, 2004). Lee and Ma (2012) believed the value of media entertainment was attributed to the ability to satisfy users' needs for escapism, enjoyment, emotional release, and anxiety relief. However, another possible explanation was that the Internet not only satisfied basic information needs but also provided enjoyment through interaction. The following hypotheses were suggested:

$\mathrm{H} 3$ : Entertainment would encourage members of social networking websites to engage in a brand community.

H3a : Entertainment would cause a low-level engagement in a brand community by members of social networking websites.

$\mathrm{H} 3 \mathrm{~b}$ : Entertainment would cause high-level engagement in brand community by members of social networking websites.

\section{- Reputation}

Reputation is defined as the extent to which consumers believe that a website is honest and concerned about its customers based on its past performance. Kim and Park (2013) believed a good reputation was a valuable intangible asset for many e-retailers and provided consumers with potential cues for enhancing trust. In terms of the characteristics of social commerce, the reputation of the social commerce firm, is 
mostly defined as the extent to which consumers believe that a firm is honest and concerned about its customers. A firm with a good reputation or image enjoys its customers' trust. The following hypotheses were suggested:

$\mathrm{H} 4$ : Reputation would encourage members of social networking websites to engage in a brand community.

H4a : Reputation would cause a low-level engagement in a brand community by members of social networking websites.

$\mathrm{H} 4 \mathrm{~b}$ : Reputation would cause high-level engagement in brand community by members of social networking websites.

\section{- Interaction}

Interaction is an individual's degree of exchange with a stranger on a social networking website. When a user has higher level of interaction in a social networking community, he or she will be more inclined to recommend the brand community, because of the benefit from engagement (Woisetschläger et al., 2008). Ayeh et al. (2013) mentioned common interest, value, and passion as the basis for consumer interaction. Cheng and Guo (2015) argued that posts of comment or praise, would attract more replies. Therefore, number of replies might be viewed as mark of personal achievement. Social networking interaction indicated more replies because these posts made people feel good. The following hypotheses were suggested:

H5 : Interaction would encourage members of social networking websites to engage in brand community.

H5a : Interaction would cause a low-level engagement in a brand community by members of social networking websites.

$\mathrm{H} 5 \mathrm{~b}$ : Interaction would cause high-level engagement in brand community by members of social networking websites.

\section{- Similarity}

Kim et al. (2004) identified similarity as members of virtual network with common interest and passion. Lu et al. (2010) argued that similarity included common value and the same belief in behavior, target, and trust among members, plus the similarity in the web content. Kunz and Sechadri (2015) stated that social networking community provided an opportunity for users to find members with similar interests and characteristics. The following hypotheses were suggested:

H6 : Similarity would encourage members of social networking websites to engage in brand community. 
H6a : Similarity would cause a low-level engagement in a brand community by members of social networking websites.

H6b : Similarity would cause high-level engagement in brand community by members of social networking websites.

\section{- Connectedness}

Zhao and $\mathrm{Lu}$ (2012) believed that connectedness was the reflection of a close relationship acquired by users through a specific technology, in order to realize the need of feeling to be close or connected to others. Mohamed and Ahmad (2012) also said that in a social networking website, users were more willing to disclose information to feel connected to friends and gain a sense of belonging. Srinivasan et al. (2012) concluded that virtual social network could be best described as an online community product to provide service in maintaining comments and information exchange. The following hypotheses were suggested:

H7 : Connectedness would encourage members of social networking websites to engage in brand community.

H7a: Connectedness would cause a low-level engagement in a brand community by members of social networking websites.

H7b: Connectedness would cause high-level engagement in brand community by members of social networking websites.

\section{Sense of Virtual Community and Equity}

In addition to being committed to interacting with consumers and the benefits of the community, the marketing staff are more concerned about the management of brand community on whether it can increase consumers' community identity and their loyalty, and enhance brand awareness and loyalty, to benefit from the brand community. Blanchard and Markus (2004) found more literature in discussing feelings and behaviors of members of virtual social network and concluded that the sense of community and feelings among members were also an important concept. Laroche et al. (2012) mentioned that social media could maintain the connection between brand users and other members to promote information and resource sharing. Therefore, this study will use the sense of community and brand equity to measure the effectiveness of the brand community.

\section{- Sense of virtual community}

Hagel and Armstrong (1997) pointed out that virtual communities need to have relationships between people with similar interests. Relationships are formed by 
individuals who want to share an experience. Blanchard and Markus (2004) also believed the sense of community as a spirit of belonging together (membership). Example feelings of membership(feelings of belonging to, and identifying with, the community or feelings of being supported by others in the community while also supporting them) Furthermore, Cheng and Guo (2015) mentioned the connection of sense of community with the interaction of brand community quality. Koh and Kim (2001) argued that three factors affected the sense of virtual community: community sentiment, community impact and community identity, and that similarity among virtual community members could significantly influence each other. This study will focus on Koh \& Kim (2001), summarizing the community awareness generated by the three major brand communities, social membership, social influence, and social identity.

\section{(1) Social Membership}

Blanchard and Markus (2004) viewed the sense of community as a spirit of belonging together (membership). Koh and Kim (2001) highlighted the importance of the perceived membership in communities for users. Kim et al. (2004) proposed that membership enhanced members' confidence and created a sense of entitlement. It also served to build loyalty to the group. The online virtual community is similar to a social community in that it allows for social interaction among its members using the Internet.

\section{(2) Social Influence}

Social influence refers to the impact of community on members and vice versa, to promote cohesion and consistency (Abfalter et al. 2012). Koh and Kim (2001) viewed social influence as impact on the community and members. Blanchard and Markus (2004) viewed the sense of virtual community as a member's feeling toward his or her influence on the community and vice versa.

\section{(3) Social Identity}

Blanchard and Markus (2004) viewed the sense of virtual community as an awareness that trade and mutual benefit came from being together, where users were supported by each other. Tsiotsou (2015) proposed that social identification involved both cognitive self-categorization and affective commitment. Thus, community identification may lead to group-oriented attitudes and behaviors expressed as engagement in group discussions and activities, and increased engagement with the SNS group and intentions to remain in the community or recommend it to others. The following hypotheses were suggested:

H8 : More engagement would indicate stronger sense of virtual community.

H8a : More low level engagement would indicate stronger sense of virtual community. 
H8b : More high level engagement would indicate stronger sense of virtual community.

\section{- Brand Equity}

Keller (1993) defined brand equity as the different effect on consumers' response to the branding of brand awareness. Dehghani and Tumer (2015) concluded that the brand equity was clearly the product advantage given by the brand name. High brand awareness can significantly influence the market share of a brand, and causes the formation of other branding elements, such as brand image, brand equity, and brand loyalty (Barreda et al., 2015). Aaker (1991) listed four dimensions of brand equity: brand awareness, perceived quality, brand association, and brand loyalty. Kim and Kim (2005) used brand awareness, perceived quality, brand image, and brand loyalty for brand equity. Han et al. (2015) combined the findings of Aaker (1991) and Kim (2005) to list brand impact, brand awareness, and brand association. Therefore, this study uses brand association, brand awareness, and brand loyalty to analyze brand equity.

\section{Brand Association}

Brand association is anything that can link to the memory of a brand, including the personal value consumers attach to the brand attributes. Keller (1993) defined brand association as a connecting point between information and brand in a consumer's memory that information included specific product attributes, such as price, logo, and brand commercials, as well as word-of-mouth and the consumer's past experience. Aaker (1991) believed that brand association could familiarize a consumer with the brand name and it was considered as one of the most important factors in shaping the brand image.

\section{Brand Awareness}

Han et al. (2015) argued that brand awareness served as a strength in consumer's mind about a brand, allowing consumer to understand and recollect the core of the brand, in order to increase brand equity. The correlation of a brand name from brand awareness represents the possibility of rooting the name of a specific brand in consumer's mind. Matthew et al. (2014) discovered that brand awareness could help to build reputation that was the essence of loyalty, where consumer would trust a brand to improve its reputation (Davies et al., 1998; Macdonald et al., 2003). 


\section{Brand Loyalty}

Brand loyalty has been defined as "a deeply held commitment to re-purchase or re-patronize a preferred product/service consistently in the future, thereby causing repetitive same-brand or same-brand-set purchasing" (Chiu et al., 2013; Oliver, 1999). Munnukka et al. (2015) concluded that re-purchase intention was defined as a measure of brand loyalty intention and purchase loyalty. Positive WOM communication was an outcome of attitudinal loyalty and re-purchase intention. Thus, brand loyalty has both attitudinal and behavioral aspects. Laroche et al. (2012) proposed that one of the main consequences of building and enhancing brand communities and consumer experience within a brand community was to make customers loyal to the brand. Srinivasan, et al. (2012) believed that virtual community could promote user and other community members communication to further enhance brand loyalty. The following hypotheses were suggested:

H9 : More active engagement would indicate stronger brand equity.

H9a : A lower level of engagement would indicate stronger brand equity.

$\mathrm{H} 9 \mathrm{~b}$ : A higher level of engagement would indicate stronger brand equity.

\section{RESEARCH METHODOLOGY}

\section{Data Analysis and Results}

According to the literature summarized in this study, the PLS path analysis of the significant impact of characteristics of a social networking site as an index on engagement behavior in brand community impacts, that the overall model path analysis results were shown in Figure 3-1.

\section{Data Collection and Sample}

The present study was based on the literature review, research hypotheses, and expert interviews. Through basic scales from the literature and organized comments from expert interviews, this study established the operational definition of various measurement variables and tested the degree of innovation diffusion; 76 items were designed. According to ICONOSQUARE and OPUSfidelis reports, three industries (mobile phone, retailing, and apparel clothing) and nine brands (Apple, Samsung, HTC for mobile phone manufacturers; 7-Eleven, PXMart and Familymart for retailers; Uniqlo, Lativ and H\&M for apparel brands) were selected to investigate the social marketing impacts among these industries and brands.

This study conducted a web survey from SNS users from Insightxplorer's CyberPanel. The samples were collected through a stratified quota sampling method. After 
removing samples with incorrect data or incomplete basic information, 920 effective samples remained. The sample profile was presented in Table 3-1.

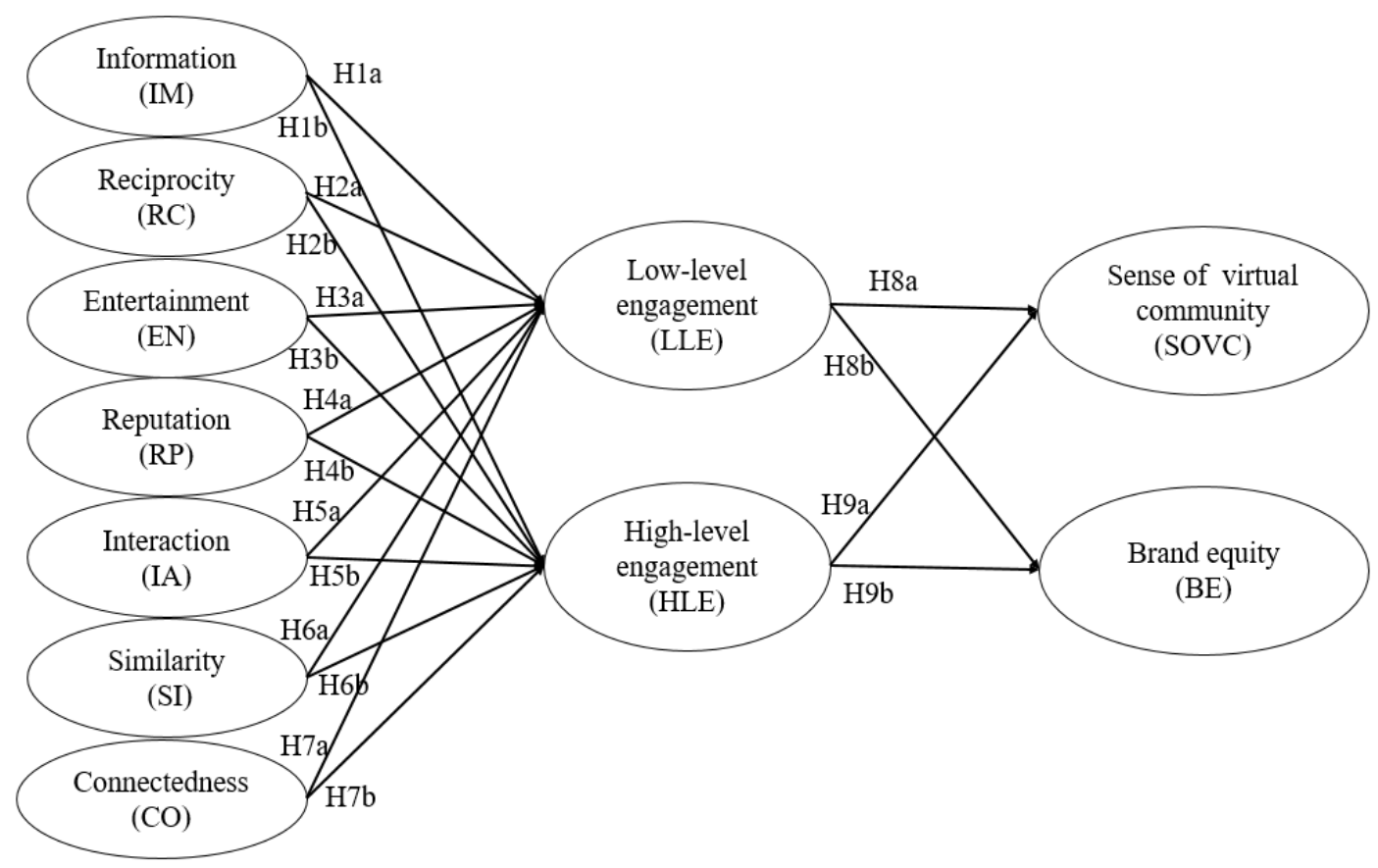

Figure 3-1 Conceptual framework

Table 3-1 Sampling Profile $(\mathrm{N}=920)$

\begin{tabular}{|l|l|l|}
\hline Gender & Frequency & Proportion(\%) \\
\hline Male & 448 & $48.7 \%$ \\
\hline Female & 472 & $51.3 \%$ \\
\hline Age & Frequency & Proportion(\%) \\
\hline $20-29$ years old & 316 & $34.3 \%$ \\
\hline $30-39$ years old & 315 & $34.2 \%$ \\
\hline Over 40 years & 289 & $31.4 \%$ \\
\hline
\end{tabular}

\section{Credibility and Validity}

Based on the measurement items developed from previous literature, LISREL8.80 was used to confirm the construct of each item. The results of the analysis were X2 / df $=2.74, \mathrm{RMSEA}=0.051$, NFI $=0.99$, IFI $=0.99$, NNFI $=0.99$, $\mathrm{CFI}=0.99$, and PGFI $=0.71$, respectively, showing that the measurement model proposed in this study fit the model. 
Confirmatory factor analysis (CFA) was performed by LISREL8.80 statistical software to test discriminant and convergent validity. Important measurement values included the component reliability (CR) and the average variation extracted (AVE). Fornell and Larcker (1981) argued that the measure of convergent reliability must meet three criteria. First, the factor loadings must be greater than 0.5 , followed by the value of component reliability (CR) greater than 0.7 , and lastly the value of average variation extracted (AVE) greater than 0.5. From Table 4-6, the factor loadings of measurements on the official questionnaire were above 0.6 , and the component reliability (CR) of each construct was above the standard of 0.9 and the AVE values were more than 0.6 , showing well above convergent reliability of the proposed construct.

The 12 proposed constructs were analyzed for discriminant reliability by the concept of community participation in the brand, the characteristics of social networking sites, and the efficacy of brand community. The square root of AVE of diagonal construct could be seen in Table 3-2. They were all greater than the correlation coefficients of other constructs, matching the proposed standard of discriminant reliability by Fornell and Larcker (1981), demonstrating a good discrimination among the constructs in the study.

Table 3-2 AVE result

\begin{tabular}{|c|c|c|c|c|c|c|c|c|c|c|c|}
\hline & $\begin{array}{c}\text { Low-level } \\
\text { engagement }\end{array}$ & $\begin{array}{c}\text { High-level } \\
\text { engagement }\end{array}$ & Information & Reciprocity & Entertainment & Reputation & Interaction & Similarity & Connectedness & $\begin{array}{c}\text { Sense of vitual } \\
\text { community }\end{array}$ & $\begin{array}{c}\text { Brand } \\
\text { equity }\end{array}$ \\
\hline $\begin{array}{c}\text { Low-level } \\
\text { engagement }\end{array}$ & 0.83 & & & & & & & & & & \\
\hline $\begin{array}{c}\text { High-level } \\
\text { engagement }\end{array}$ & 0.76 & 0.89 & & & & & & & & & \\
\hline Information & 0.70 & 0.54 & 0.85 & & & & & & & & \\
\hline Reciprocity & 0.67 & 0.65 & 0.70 & 0.88 & & & & & & & \\
\hline Entertainment & 0.73 & 0.57 & 0.77 & 0.78 & 0.89 & & & & & & \\
\hline Reputation & 0.65 & 0.44 & 0.74 & 0.63 & 0.76 & 0.90 & & & & & \\
\hline Interaction & 0.66 & 0.78 & 0.55 & 0.72 & 0.62 & 0.51 & 0.94 & & & & \\
\hline Similarity & 0.68 & 0.65 & 0.69 & 0.73 & 0.72 & 0.66 & 0.72 & 0.87 & & & \\
\hline Connectedness & 0.70 & 0.73 & 0.67 & 0.77 & 0.72 & 0.62 & 0.83 & 0.85 & 0.88 & & \\
\hline Sense of virtual \\
community
\end{tabular}




\section{RESULTS AND ANALYSIS}

\section{PLS Results}

In this study, the cause of brand community could be divided into the characteristics and the benefits of social networking site. Information would cause a low-level and high-level engagement in a brand community by members of social networking websites. Therefore H1a and H1b hypothesis is Supported. However, high level of user perception of reciprocity in brand community would not promote either low or high level of engagement, and thus, hypotheses $\mathrm{H} 2_{\mathrm{a}}(\beta=0.265, \mathrm{t}=0.242)$, $\mathrm{H} 2 \mathrm{~b}(\beta=0.265, \mathrm{t}=1.747)$. When users perceived more entertainment in brand community, they would commit to low-level engagement, but not high-level engagement, so $\mathrm{H}_{3} \mathrm{a}(\beta=0.265, \mathrm{t}=5.476)$ was valid, but $\mathrm{H} 3 \mathrm{~b}(\beta=0.042$, $\mathrm{t}=0.971)$ was not. When users perceived more reputation and interaction in brand community, to brand community could enhance both the low and the high degrees of engagement. Thus, the hypotheses $\mathrm{H} 4_{\mathrm{a}}(\beta=0.108, \mathrm{t}=2.866), \quad \mathrm{H} 4_{\mathrm{b}}(\beta=-0.113, \mathrm{t}=3.458) . \quad \mathrm{H} 5 \mathrm{a}(\beta=0.228, \mathrm{t}=3.802) \quad$ and $\mathrm{H} 5 \mathrm{~b}(\beta=0.547, \mathrm{t}=12.316)$ were valid. However, high level of user perception of similarity in brand community would not promote either a low or a high level of engagement, meaning that hypotheses $\mathrm{H}_{\mathrm{a}}(\beta=0.061, \mathrm{t}=1.196)$ and $\mathrm{H} 6_{\mathrm{b}}(\beta=0.061$, $\mathrm{t}=1.410$ ) were invalid. In addition, when users felt more connected to brand community, they would engage in high-level of engagement, and thus, $\mathrm{H} 7_{\mathrm{a}}(\beta=00.061$, $\mathrm{t}=0.852)$ was invalid, but $\mathrm{H} 7 \mathrm{~b}(\beta=0.133, \mathrm{t}=2.549)$ was valid. In the following section, the impact of benefits of social networking site as index on engagement behavior in brand community is discussed. Users who have both low and high levels of engagement would understand community awareness and brand equity, thus, hypotheses $\mathrm{H} 8_{\mathrm{a}}(\beta=0.243, \mathrm{t}=6.460), \mathrm{H} 8_{\mathrm{b}}(\beta=0.566, \mathrm{t}=14.088), \mathrm{H} 9_{\mathrm{a}}(\beta=0.589, \mathrm{t}=15.639)$ and $H 9_{b}(\beta=0.186, t=4.930)$ were all valid.

\section{Multi-Group}

The data of each group are summarized in Table 4-1. After the data of the three types of samples were organized, for the characteristics of social networking sites, information for user's brand awareness was effective for user's low-level engagement in mobiles phones' communities, retailers' communities, and apparels' communities, and the effect was more profound for apparels' communities than mobile phones' communities, suggesting stronger emphasis on information of brand community for apparels' communities. As for high-level engagement, information of brand community was more effective for mobile phones' communities. For the reciprocity of user's awareness of brand community, the information was effective for users having 
both low and high levels of engagement in mobiles phones' communities and but not for other two kinds of products' communities. For the entertainment of a brand community, neither low-level nor high-level engagement user has significant awareness on engagement, it was useful for retailers' communities and apparels' communities, but not for mobile phones' communities, but if high-level engagement, the brand community had no effect. Reputation and low-level engagement were effective only for mobile phones' communities, but did induce high-level engagement for apparels' communities. In interaction of user's awareness of brand community, it could induce low-level engagement in retailers and apparels' communities, and even the three categories for high-level engagement. Lastly, user's awareness of similarity and connectedness by brand community did not induce either low- or high-level engagement for all three categories. Furthermore, user's awareness of brand community to induce low-level engagement, regardless of community awareness or brand equity, information was effective for all three categories. Inducing high-level engagement and community awareness was effective for all three categories, but for brand equity, only the categories of mobile phones' communities and retailers' communities were affected.

\section{CONCLUSION}

In conclusion, this study will discuss the following two key point in this chapter :1. Analyze the cause and the correlation among engagement behavior, service characteristics and benefits of brand community for each brand; 2. Describe the theoretical contribution of this study to further provide practical recommendation and application for each brand by distinguishing marketing properties of brand community and future outlook.

In all brands, when users perceived more in information, reciprocity, reputation and interaction in brand community, these qualities promoted low and high levels of engagement. The finding was similar to that of Lee and Ma (2012), who proposed that information on a social networking site could be shared among users. It is also similar to research by Yoo et al. (2015) and Koh and Kim (2001), who proposed that reciprocity could strongly affect behaviors among users due to passion and similarity. Moreover, entertainment and similarity of brand community would be ineffective in promoting low and high levels of engagement, suggesting the need to improve these qualities for each brand to enhance their engagement. Lastly, when all brand users having low and high levels of engagement, the behavior could still improve community awareness and brand equity of brand community. Gavard-Perret (2015) 
suggested that promise of a brand from community was connected to a mutually dependent relationship between community engagement and brand loyalty.

Table 4-1 PLS Result and Multi-Group Analysis

\begin{tabular}{|l|c|c|c|c|}
\hline & $\begin{array}{c}\text { All brand } \\
\text { communities }\end{array}$ & $\begin{array}{c}\text { Mobile phone } \\
\text { manufacturer } \\
\text { brands' } \\
\text { communities }\end{array}$ & $\begin{array}{c}\text { Retailers } \\
\text { brands' } \\
\text { communities }\end{array}$ & $\begin{array}{c}\text { Apparel } \\
\text { brands' } \\
\text { communities }\end{array}$ \\
\hline $\mathrm{H}_{1 \mathrm{a}}: \mathrm{IM} \rightarrow \mathrm{LLE}$ & $0.214^{* * *}$ & $0.184^{*}$ & $0.274^{* * *}$ & $0.224^{* *}$ \\
\hline $\mathrm{H}_{\mathrm{b}}: \mathrm{IM} \rightarrow \mathrm{HLE}$ & $0.113^{* *}$ & $0.171^{*}$ & 0.082 & 0.281 \\
\hline $\mathrm{H}_{2 \mathrm{a}}: \mathrm{RC} \rightarrow \mathrm{LLE}$ & -0.012 & $0.154^{*}$ & -0.143 & 0.069 \\
\hline $\mathrm{H}_{2 \mathrm{~b}}: \mathrm{RC} \rightarrow \mathrm{HLE}$ & 0.066 & $0.223^{* *}$ & -0.017 & 0.066 \\
\hline $\mathrm{H}_{3 \mathrm{a}}: \mathrm{EN} \rightarrow \mathrm{LLE}$ & $0.265^{* * *}$ & 0.061 & $0.388^{* * *}$ & $0.265^{* *}$ \\
\hline $\mathrm{H}_{3 b}: \mathrm{EN} \rightarrow \mathrm{HLE}$ & 0.042 & -0.092 & 0.113 & 0.035 \\
\hline $\mathrm{H}_{4 a}: \mathrm{RP} \rightarrow \mathrm{LLE}$ & $0.108^{* *}$ & $0.158^{*}$ & 0.084 & 0.066 \\
\hline $\mathrm{H}_{4 b}: \mathrm{RP} \rightarrow \mathrm{HLE}$ & $-0.113^{* * *}$ & -0.096 & -0.075 & $-0.139^{*}$ \\
\hline $\mathrm{H}_{5 \mathrm{a}}: \mathrm{IA} \rightarrow \mathrm{LLE}$ & $0.228^{* * *}$ & 0.203 & $0.217^{* *}$ & $0.281^{* *}$ \\
\hline $\mathrm{H}_{5 b}: \mathrm{IA} \rightarrow \mathrm{HLE}$ & $0.547^{* * *}$ & $0.430^{* * *}$ & $0.628^{* * *}$ & $0.586^{* * *}$ \\
\hline $\mathrm{H}_{6 \mathrm{a}}: \mathrm{SI} \rightarrow \mathrm{LLE}$ & 0.061 & 0.038 & 0.080 & -0.000 \\
\hline $\mathrm{H}_{6 b}: \mathrm{SI} \rightarrow \mathrm{HLE}$ & 0.061 & 0.063 & 0.063 & 0.049 \\
\hline $\mathrm{H}_{7 \mathrm{a}}: \mathrm{CO} \rightarrow \mathrm{LLE}$ & 0.061 & 0.127 & 0.048 & -0.002 \\
\hline $\mathrm{H}_{7 b}: \mathrm{CO} \rightarrow \mathrm{HLE}$ & $0.133^{*}$ & 0.179 & 0.058 & 0.139 \\
\hline $\mathrm{H}_{8 \mathrm{a}}: \mathrm{LLE} \rightarrow \mathrm{SOVC}$ & $0.243^{* * *}$ & $0.180^{*}$ & $0.272^{* * *}$ & $0.255^{* * *}$ \\
\hline $\mathrm{H}_{8 b}: \mathrm{LLE} \rightarrow \mathrm{BE}$ & $0.566^{* * *}$ & $0.492^{* * *}$ & $0.535^{* * *}$ & $0.642^{* * *}$ \\
\hline $\mathrm{H}_{9 \mathrm{a}}: \mathrm{HLE} \rightarrow \mathrm{SOVC}$ & $0.589^{* * *}$ & $0.675^{* * *}$ & $0.521^{* * *}$ & $0.576^{* * *}$ \\
\hline $\mathrm{H}_{96}: \mathrm{HLE} \rightarrow \mathrm{BE}$ & $0.186^{* * *}$ & $0.288^{* * *}$ & $0.197^{* * *}$ & 0.085 \\
\hline
\end{tabular}

$$
*=\mathrm{p}<0.05 ;^{* *}=\mathrm{p}<0.01 ; * * *=\mathrm{p}<0.001
$$

In the category of mobile phones' communities, the significant effect of brand community on engagement was investigated through test result of characteristics of social networking site, when user's perception relied on the level of information and reciprocity from brand community to encourage users having in both low and high levels of engagement. The finding was similar to the result seen in the category of all brands, as the result demonstrated the importance of accuracy and abundance of information about mobile phones' communities for users. However, when users perceived a higher value of entertainment, similarity and connectedness to a brand 
community of mobile phones' communities, these would not encourage either low or high levels of engagement by users, which suggested the need to improve the values of entertainment, similarity and connectedness for brands of mobile phones' communities to encourage more participants. In addition, when users having both low and high levels of engagement, the behavior could still improve the sense of community and brand equity in a brand community of mobile phones' communities, the finding was similarity with the result seen in the category of all brand.

As for the category of retailers' communities, in the overall sample, higher level of user's perception of reciprocity, reputation, similarity and connectedness with the brand community would not enhance either low or high level of engagement, indicating the need to strengthen these characteristics in brand community for retailers' communities to improve degree of engagement. When users perceived more interaction with brand community, it would encourage low and high levels of engagement by users, which coincided with Zhao and $\mathrm{Lu}$ (2012) and Woisetschläger et al. (2008) in their proposal that high interaction in a community could push users to recommend the brand community. When users having in both low and high levels of engagement, the behavior could still improve the sense of community and brand equity in a brand community, in similarity with the result seen in the category of mobile phones' communities.

In the category of apparels' communities, higher level of user's perception of information and entertainment with the brand community would enhance only low-level instead of high-level engagement, while high level of reciprocity, similarity and connectedness to a brand community as perceived by users would not encourage users in either low or high level of engagement, indicating the need to strengthen these characteristics in brand community for retail channel to improve degree of engagement. When users perceived more interaction with brand community, it would encourage low and high levels of engagement by users, which coincided with result from the analysis of retail channel. Moreover, when users participated more in high-level, it would not promote brand equity of a brand community, which suggested that brand of apparels' communities should strengthen behavioral engagement in commenting, sharing and creating to improve brand equity.

Multi-Group Analysis showed that information of brand community as perceived by users to engage in low-level of engagement was more useful in the category of apparels' communities commodities than mobile phones' communities, suggesting more focus on brand community for apparels' communities, where engagement for members of brand community in apparels' communities corresponded with the study result of Lee and Ma (2012) who believed that the search of information required the 
sharing of information in social networking media to provide immediate and relevant data for the users. For other group comparisons, there was no statistical significance.

In terms of theoretical contributions, this research studied the influence of diverse brand communities on engagement behavior and the advantages to a virtual brand. The findings of this study can fill the gap in academic research on brand communities and provide a basis for future research of brand communities to further investigate the variations between several brands and brand communities, and they can facilitate relevant academic studies on future applications of information for social network marketing and brand communities.

Regarding practical contributions, this study produced PLS results by analyzing the correlation between engagement behavior in a brand community, the characteristics of social networking sites, and the efficacy of brand communities. These results could allow marketing personnel to understand the differences between each brand in the brand community. The results can also serve as evidence to draft a better strategy for future brand community marketing. Through a comparison of the results for the three categories, they must all enhance the entertainment, similarity, and connectedness of the brand community to improve users' awareness. Retailers and apparels community outlets must improve the characteristics of their social networking sites. According to the research results, brand marketing personnel can view the outstanding brand as a model for studying the brand's community properties; brands with poorer performance in brand communities should be improved to remove the inadequacies.

Finally, limitations and future study recommendations are provided. Since the study collected information only from Taiwanese internet users, future research should expand to include others for comparison. In addition, due to time and budget constraints, the study targeted only the nine most popular brands. Based on the research restriction and recommendation for future studies, we provide reference materials for social media advertisement and have identified important factors in influencing brand community.

\section{REFERENCES}

Abfalter, D., Zaglia, M. E., \& Mueller, J. (2012). Sense of virtual community: A follow up on its measurement. Computers in Human Behavior, 28(2), 400-404. http://dx.doi.org/10.1016/j.chb.2011.10.010

Ayeh, J. K., Au, N., \& Law, R. (2013). Predicting the intention to use consumer-generated media for travel planning. Tourism Management, 35(12), 132-143. http://dx.doi.org/10.1016/j.tourman.2012.06.010 
Barreda, A. A., Bilgihan, A., Nusair, K., \& Okumus, F. (2015). Generating brand awareness in Onne Social Networks. Computers in Human Behavior, 50, 600-609.

Blanchard, A. L., \& Markus, M. L. (2004). The experienced sense of a virtual community: Characteristics and processes. ACM Sigmis Database, 35(1), 64-79. http://dx.doi.org/10.1145/968464.968470

Brodie, R. J., Ilic, A., Juric, B., \& Hollebeek, L. (2013). Consumer engagement in a virtual brand community: An exploratory analysis. Journal of Business Research, 66(1), 105-114. http://dx.doi.org/10.1016/j.jbusres.2011.07.029

Chan, K. W., \& Li, S. Y. (2010). Understanding consumer-to-consumer interactions in virtual communities: The salience of reciprocity. Journal of Business Research, 63(9), 1033-1040. http://dx.doi.org/10.1016/j.jbusres.2008.08.009

Chen, R. (2013). Living a private life in public social networks: An exploration of member self-disclosure. Decision Support Systems, 55(3), 661-668. http://dx.doi.org/10.1016/j.dss.2012.12.003

Cheng, Z. C., \& Guo, T. C. (2015). The formation of social identity and self-identity based on knowledge contribution in virtual communities: An inductive route model. Computers in Human Behavior, 43, 229-241. http://dx.doi.org/10.1016/j.chb.2014.10.056

Chiu, C. M., Cheng, H. L., Huang, H. Y., \& Chen, C. F. (2013). Exploring individuals' subjective well-being and loyalty towards social network sites from the perspective of network externalities: The Facebook case. International Journal of Information Management, 33(3), 539-552.

Ellahi, A., \& Bokhari, R. H. (2013). Key quality factors affecting users' perception of social networking websites. Journal of Retailing and Consumer Services, 20(1), 120-129. http://dx.doi.org/10.1016/j.jretconser.2012.10.013

Evans, D. (2010). Social media marketing: the next generation of business engagement. John Wiley \& Sons, IN: Wiley Publishing, Inc.

Fornell, C., \& Larcker, D. F. (1981). Evaluating structural equation models with unobservable variables and measurement error. Journal of marketing research, 39-50.

Fournier, S., \& Avery, J. (2011). The uninvited brand. Business Horizons, 54(3), 193-207. http://dx.doi.org/10.1016/j.bushor.2011.01.001

Franzia, E., Piliang, Y. A., \& Saidi, A. I. (2015). Manifestation of Minangkabau Cultural Identity through Public Engagement in Virtual Community. Procedia-Social and Behavioral Sciences, 184, 56-62. http://dx.doi.org/10.1016/j.sbspro.2015.05.053 
Hagel, J., \& Armstrong, A. (1997). Net gain: Expanding markets through virtual communities. Harvard Business

Press. http://dx.doi.org/10.1007/978-3-322-84687-7

Han, S. H., Nguyen, B., \& Lee, T. J. (2015). Consumer-based chain restaurant brand equity, brand reputation, and brand trust. International Journal of Hospitality Management, 50, 84-93. http://dx.doi.org/10.1016/j.ijhm.2015.06.010

Hanna, R., Rohm, A., \& Crittenden, V. L. (2011). We're all connected: The power of the social media ecosystem. Business Horizons, 54(3), 265-273.

Ho, L. A., Kuo, T. H., \& Lin, B. (2012). The mediating effect of website quality on Internet searching behavior. Computers in Human Behavior, 28(3), 840-848. http://dx.doi.org/10.1016/j.chb.2011.11.024

Keller, K. L. (1993). Conceptualizing, measuring, and managing customer-based brand equity. The Journal of Marketing, 1-22. http://dx.doi.org/10.2307/1252054

Kim, S., \& Park, H. (2013). Effects of various characteristics of social commerce (s-commerce) on consumers' trust and trust performance. International Journal of Information Management, 33(2), 318-332.

Kim, W. G., Lee, C., \& Hiemstra, S. J. (2004). Effects of an online virtual community on customer loyalty and travel product purchases. Tourism management, 25(3), 343-355. http://dx.doi.org/10.1016/S0261-5177(03)00142-0

Kim, Y. H., Kim, D. J., \& Wachter, K. (2013). A study of mobile user engagement (MoEN): Engagement motivations, perceived value, satisfaction, and continued engagement intention. Decision Support Systems, 56, 361-370. http://dx.doi.org/10.1016/j.dss.2013.07.002

Koh, J., \& Kim, Y. G. (2001). Sense of virtual community: Determinants and the moderating role of the virtual community origin. ICIS 2001 Proceedings, 47.

Kunz, W., \& Seshadri, S. (2015). From virtual travelers to real friends: Relationship-building insights from an online travel community. Journal of business research, 68(9), 1822-1828.

Li, D. C. (2011). Online Social Network Acceptance: a Social Perspective. Internet Research, 21(5), 562-580.

Lu, Y., Zhao, L., \& Wang, B. (2010). From virtual community members to C2C e-commerce buyers: Trust in virtual communities and its effect on consumers' purchase intention. Electronic Commerce Research and Applications, 9(4), 346-360. http://dx.doi.org/10.1016/j.elerap.2009.07.003

Landry, T. D., Arnold, T. J., \& Stark, J. B. (2005). Retailer community embeddedness and consumer patronage. Journal of Retailing and Consumer Services, 12(1), 65-72. http://dx.doi.org/10.1016/j.jretconser.2004.03.001 
Laroche, M., Habibi, M. R., Richard, M. O., \& Sankaranarayanan, R. (2012). The effects of social media based brand communities on brand community markers, value creation practices, brand trust and brand loyalty. Computers in Human Behavior, 28(5), 1755-1767. http://dx.doi.org/10.1016/j.chb.2012.04.016

Lee, C. S., \& Ma, L. (2012). News sharing in social media: The effect of gratifications and prior experience. Computers in Human Behavior, 28(2), 331-339. http://dx.doi.org/10.1016/j.chb.2011.10.002

Macdonald, E., \& Sharp, B. (2003). Management perceptions of the importance of brand awareness as an indication of advertising effectiveness. 1st ed. Massey University, Department of Marketing.

Mohamed, N., \& Ahmad, I. H. (2012). Information privacy concerns, antecedents and privacy measure use in social networking sites: Evidence from Malaysia. Computers in Human Behavior, 28(6), 2366-2375. http://dx.doi.org/10.1016/j.chb.2012.07.008

Munnukka, J., Karjaluoto, H., \& Tikkanen, A. (2015). Are Facebook brand community members truly loyal to the brand. Computers in Human Behavior, 51, 429-439. http://dx.doi.org/10.1016/j.chb.2015.05.031

Nadeem, W., Andreini, D., Salo, J., \& Laukkanen, T. (2015). Engaging consumers online through websites and social media: A gender study of Italian Generation Y apparel consumers. International Journal of Information Management, 35(4), 432-442.

Raïes, K., Mühlbacher, H., \& Gavard-Perret, M. L. (2015). Consumption community commitment: Newbies' and longstanding members' brand engagement and loyalty. Journal of Business Research.

Srinivasan, S. S., Anderson, R., \& Ponnavolu, K. (2002). Customer loyalty in e-commerce: an exploration of its antecedents and consequences. Journal of retailing, 78(1), 41-50. http://dx.doi.org/10.1016/S0022-4359(01)00065-3

Strauss, J., Frost, R., \& Ansary, A. I. (2009). E-marketing. Pearson Prentice Hall.

Strauss, J., \& Frost, R. (2013). E-Marketing: Pearson New International Edition (6. bs.). Essex, UK: Pearson Education Limited.

Tsai, H. T., Huang, H. C., \& Chiu, Y. L. (2012). Brand community engagement in Taiwan: Examining the roles of individual-, group-, and relationship-level antecedents. Journal of Business Research, 65(5), 676-684. .

Uzzi, B. (1996). The sources and consequences of embeddedness for the economic performance of organizations: The network effect. American sociological review, 674-698. 
Warren, R. L. (1978). The community in America. 3rd.edn.Rand McNally, Chicago, Illinois.

Woisetschläger, D. M., Hartleb, V., \& Blut, M. (2008). How to make brand communities work: Antecedents and consequences of consumer engagement. Journal of Relationship Marketing, 7(3), 237-256.

Wolfinbarger, M., \& Gilly, M. C. (2003). eTailQ: dimensionalizing, measuring and predicting etail quality. Journal of retailing, 79(3), 183-198.

Yang, K., Li, X., Kim, H., \& Kim, Y. H. (2015). Social shopping website quality attributes increasing consumer engagement, positive eWOM, and co-shopping: The reciprocating role of engagement. Journal of Retailing and Consumer Services, 24, 1-9.

Yoo, C. W., Kim, Y. J., \& Sanders, G. L. (2015). The impact of interactivity of electronic word of mouth systems and E-Quality on decision support in the context of the e-marketplace. Information \& Management, 52(4), 496-505. http://dx.doi.org/10.1016/j.im.2015.03.001

Zaglia, M. E. (2013). Brand communities embedded in social networks. Journal of Business Research, 66(2),

216-223. http://dx.doi.org/10.1016/j.jbusres.2012.07.015

Zhao, L., \& Lu, Y. (2012). Enhancing perceived interactivity through network externalities: An empirical study on micro-blogging service satisfaction and continuance intention. Decision Support Systems, 53(4), 825-834. http://dx.doi.org/10.1016/j.dss.2012.05.019

eMarketer(2015), Increasing Audience Engagement Key Objective in Social Media Marketing Retrieved: Jan 16, 2013 from: http://www.emarketer.com/Article/Increasing-Audience-Engagement-KeyObjective-Social- Media-Marketing/1013148

ICONOSQUARE(2015), The Top 14 brands on Instagram Retrieved: Jan 16, 2013 from: http://blog.iconosquare.com/top-14- brands-instagram/ 